\title{
REVIEW
}

\section{JOB SATISFACTION OF MIDWIVES: A LITERATURE REVIEW}

\author{
Daniela Nedvědová, Bohdana Dušová, Darja Jarošová \\ Department of Nursing and Midwifery, Faculty of Medicine, University of Ostrava, Czech Republic
}

Received July 13, 2016; Accepted January 10, 2017. Copyright: This is an open access article distributed under the terms of the Creative Commons Attribution International License (CC BY). http://creativecommons.org/licenses/by/4.0/

\begin{abstract}
Aim: The aims of the literature review were to identify and analyze factors affecting job satisfaction of midwives. Design: A literature review. Methods: Included in the literature review were full texts of papers published in English language from 1990 to 2014. The search for relevant data was performed using the electronic databases CINAHL, Medline, Science Direct and Wiley Online Library. From a total of 43 studies found, 11were analyzed as quantitative studies that fulfilled the specified criteria. Results: Job satisfaction of midwives is affected by a lack of support from the management of healthcare facilities, low salary, understaffing, insufficient time for professional activities, work-family imbalance, high workload, physical demands, inadequate professional development, working environment, stress and low autonomy at work. Midwives showed signs of exhaustion, fatigue, hostility and depression, contributing to job turnover. Conclusion: The literature review presents the factors influencing job satisfaction of midwives. This is affected by many variable determinants, which create a feeling of job satisfaction of midwives, but can also lead to job dissatisfaction and, consequently, high turnover.
\end{abstract}

Keywords: midwives, job satisfaction.

\section{Introduction}

Job satisfaction of health professionals has mainly been studied among nurses. In the last decade, more studies have been published on job satisfaction of midwives (Bodur, 2002; Lazarus, Rasch, Liljestrand, 2005; Casey, Saunders, O'Hara, 2010; Hammond et al., 2011; Sullivan, Lock, Homer, 2011; Rouleau et al., 2012; Papoutsis, Labiris, Niakas, 2014). However, research studies have only sporadically dealt with overall job satisfaction of midwives. Surveys in this area focus on individual factors such as burnout (Rouleau et al., 2012), stress and workload (Wheeler, Riding, 1994; Mackin, Sinclair, 1998; Dorrian et al., 2011; Sato, Adachi, 2013), demographic characteristics (Watson, Potter, Donohue, 1999), working conditions (Hampton, Peterson, 2012), and autonomy of midwives (Tummers, Den Dulk, 2013). Working alongside physicians, midwives play an important role comprising care for women, communication, education as well as managerial and research activities (Vévoda et al., 2010; Lasovská, Králová, 2011).

Corresponding author: Daniela Nedvědová, Department of Nursing and Midwifery, Faculty of Medicine, University of Ostrava, Syllabova 19, Ostrava, Czech Republic; email: daniela.nedvedova@osu.cz.
They often leave their profession or relocate for job reasons in order to find better living conditions for both themselves and their families (Sidebotham, Ahern, 2011). They negatively perceive the imbalance between their family and work life (Payne, 2010) and also look for better professional opportunities due to increasing workload. And it is high workload that, in combination with a lack of support from healthcare facility management, results in job dissatisfaction of midwives and, subsequently, a high turnover (Sidebotham, Ahern, 2011). Factors and variables such as job design, age, level of education, working conditions, co-workers, salary and working time may have a considerable impact on job satisfaction (Bodur, 2002). Moreover, job uncertainty and political instability add to these factors (Kumar et al., 2013). An important role is also played by stress (Wheeler, Riding, 1994; Mackin, Sinclair, 1998; Dorrian et al., 2011; Sato, Adachi, 2013), with midwives experiencing high workload, lack of time for professional activities, too much work with health records, physically demanding work and poor interpersonal relations with physicians. Midwives often show signs of hostility, fatigue, exhaustion and depression, sleep disorders and even are victims of road accidents on their way home from work (Dorrian et al., 2011). This is negatively reflected in their job satisfaction. Midwifery is a stressful profession that is physically demanding 
and requires considerable concentration and skills (Sato, Adachi, 2013), as well as much work effort and activity (Tummers, Den Dulk, 2013). In their profession, midwives perceive inadequate use of practical skills and knowledge and insufficient income (Tummers, Den Dulk, 2013). Uncompetitive pay is a frequently discussed issue and it is considered one of the main reasons for midwives to leave their profession (Shen, Cox, McBride, 2004).

\section{Aim}

The aims of this literature review were to identify and analyze factors influencing job satisfaction of midwives.

\section{Methods}

\section{Design}

The study design was a literature review.

\section{Eligibility criteria}

Included in the literature review were papers published between 1990 and 2014. The review only searched for full-text articles presenting results of studies related to job satisfaction of midwives. The review comprised studies of various design. Articles written in English and Czech were searched for.

\section{Sources}

The following licensed and free access electronic databases were used: CINAHL, Medline, Science Direct and Wiley Library Online.

\section{Search}

At the beginning of the search for relevant papers, the following question was formulated using the PICO format: What factors influence job satisfaction of midwives? The keywords used to search the electronic databases were midwives and job satisfaction (or the Czech words porodni asistentky and pracovni spokojenost). Given the absence of papers concerned exclusively with job satisfaction of midwives in the Czech Republic, only international electronic databases were searched. Similarly, very few relevant studies were retrieved when specifying search terms; therefore, only the above keywords were identified. The Boolean operator AND was used with the keywords; no synonyms were added.

\section{Study selection and data analyses}

The studies were selected and classified according to the recommended PRISMA standard for reviews (Moher et al., 2009) (Figure 1). The initial phase of the review focused on all records identified through database searching using the selection criteria and keywords. A total of 408 records published in English over the above period were identified. Subsequently, six duplicated were removed. Abstracts of peer-reviewed articles were read to exclude records not relevant to the topic. Given the focus of the review on job satisfaction of midwives only, another 359 studies investigating midwives together with nurses or other health professionals were excluded. As a result, 43 full-text articles were assessed for eligibility. Of those, 32 records were excluded as duplicates or articles presenting only descriptions of the issue but not research. Moreover, the articles did not deal with overall job satisfaction of midwives but only with sub-factors, in particular midwives' stress, autonomy and workload. Eventually, 11 records meeting the defined criteria were included in the literature review. Those were mostly descriptive and cross-sectional studies.

\section{Results}

Job satisfaction of midwives is influenced, both positively and negatively, by numerous factors. The results of the study provide an overview of motivators and factors most frequently identified by midwives as related to job satisfaction as well as the impact of job satisfaction on turnover and retention of midwives.

\section{Motivators of midwives' job satisfaction}

High levels of job satisfaction have been shown to be associated with less turnover and absenteeism of employees (Papoutsis, Labiris, Niakas, 2014). The authors carried out a quantitative study on job satisfaction of midwives working in both the public and private sectors. The participants mainly associated job satisfaction with autonomy, supervision and salary. Similar findings were reported by Skinner, Madison, Humphries (2012). Midwives participating in their study were highly satisfied with their job, indicating that they were suited to the work they were doing, enjoyed the type of work and did not want to leave their professional discipline They even became accustomed to stress and considered it to be a part of their profession. In an Australian study by Watson, Potter, Donohue (1999), the majority of midwives were satisfied, with interactions with women and autonomy being the most important aspects. Working relations and understaffing had a negative impact on their job satisfaction. A descriptive study by Sullivan, Lock, Homer (2011) showed that the factors contributing to job satisfaction of midwives were interactions with 


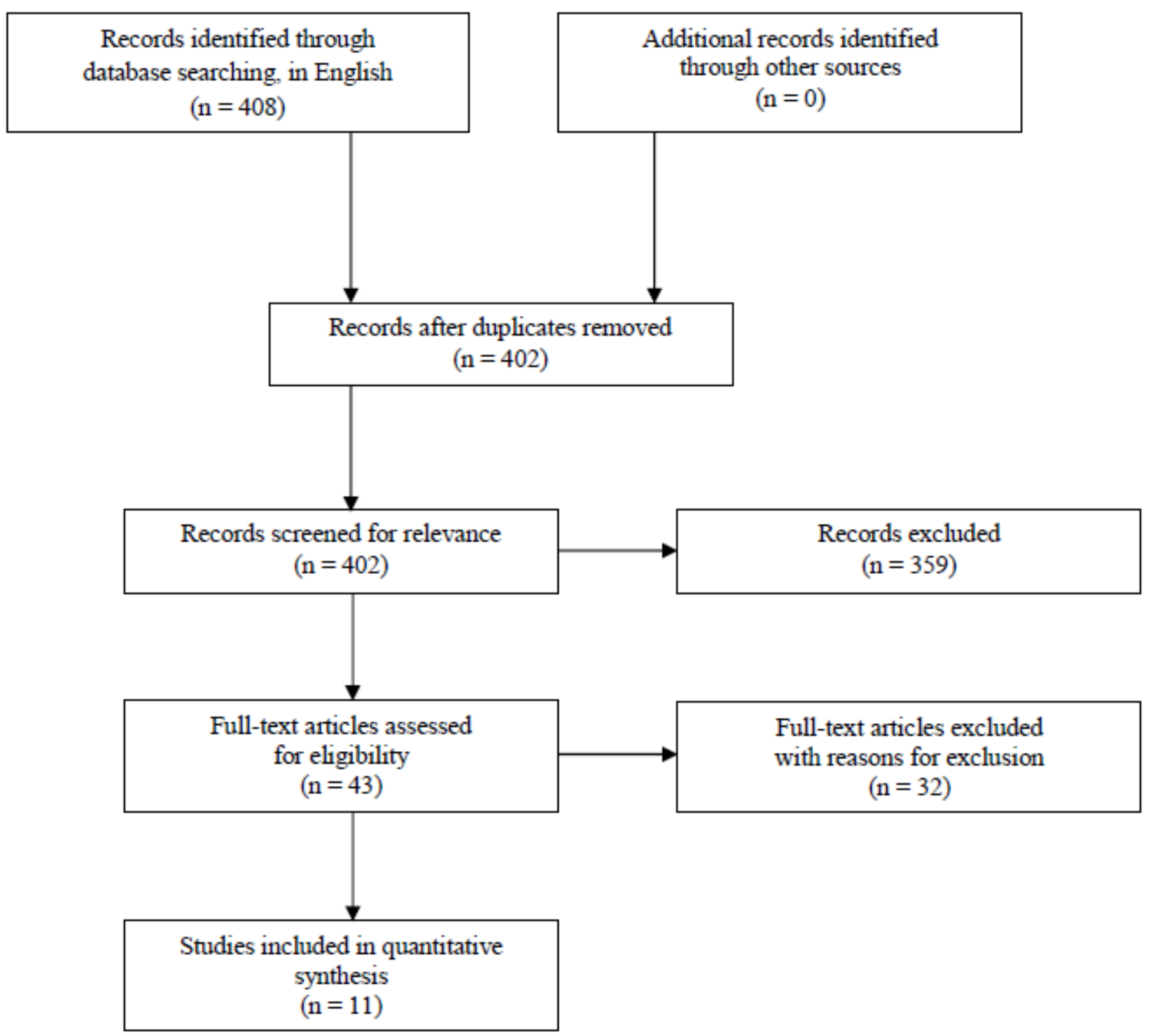

Scheme 1 Flow diagram of the selection and classification of quantitative studies on job satisfaction of midwives

pregnant women, positive responses from women they cared for, the variety of the job, autonomy within their work and feeling valued by childbearing women. Hospital midwives in a study by Todd, Farquhar, Camilleri-Ferrante (1998) had a rather neutral attitude to job satisfaction as they were limited by strict guidelines. However, community midwives were more satisfied with their job, reporting a greater variety of work and more autonomy. Community midwives used their practical skills and knowledge more than their hospital counterparts and thus could increase their professional development.

\section{Factors influencing job satisfaction}

Support at work was discussed in studies by Gardulf et al. (2008) and Curtis, Ball, Kirkham (2006). A lack of managerial support led to insufficient professional development of midwives, as reflected by their job satisfaction and, subsequently, their intention to leave the profession. Rodwell and Munro (2013) investigated the impact of workload and supervisor support on midwives' subjective well-being and attitudes towards their work. They came to the conclusion that midwives' subjective well-being and attitudes towards their work were influenced by their own workload and levels of supervisor support.

Midwives' salaries were discussed in a study by Lazarus, Rasch, Liljestrand (2005) stating that nearly a half of the participants were not satisfied with their job, with the main dissatisfier being their salary. Midwives reported variations in salaries between urban and rural areas as well as between different settings (delivery wards, antenatal departments or postpartum rooms). Dissatisfaction with salaries was 
also reported by midwives in studies by Rouleau et al. (2012) and Bodur (2002).

\section{Job satisfaction and its impact on turnover/retention of midwives}

In their review, Shen, Cox, McBride (2004) identified factors influencing retention or turnover of midwives. Turnover was contributed to by the following factors: job dissatisfaction, workload, a lack of career development, salary and unpleasant working environment. The factors contributing to retention were balance between personal and work lives, benefits and pleasant working environment including the fostering of friendship at work, more typically in private facilities. Five main reasons for leaving the profession were identified by midwives participating in a study by Ball, Curtis, Kirkham (2003). Those were dissatisfaction with midwifery practice, family, retirement, ill health and planned career change. Dissatisfaction with midwifery practice was mainly linked to discrepancies between theoretical knowledge and practice. The participants were also dissatisfied with a lack of support from the healthcare facility management and being undervalued. The midwives also felt frustrated in their profession. The opposite findings were published in an Australian study by Sullivan, Lock, Homer (2011). The reasons for staying in midwifery were enjoying the job, being proud to be midwives and getting job satisfaction. Other reasons were the opinion that midwifery is preferable to general nursing and that midwives wanted to work with women and their families. The analyzed studies on job satisfaction of midwives are summarized in Tables 1 and 2.

Table 1 An overview of studies on job satisfaction of midwives included in the literature review (quantitative research methods)

\begin{tabular}{|c|c|c|c|c|}
\hline Author(s), year & Objective & Method & Sample & Results \\
\hline $\begin{array}{l}\text { Papoutsis, } \\
\text { Labiris, Niakas, } \\
2014\end{array}$ & $\begin{array}{l}\text { To identify factors of } \\
\text { midwives' job } \\
\text { satisfaction }\end{array}$ & $\begin{array}{l}\text { A quantitative method } \\
\text { - an in-house } \\
\text { questionnaire }\end{array}$ & $\begin{array}{l}91 \text { midwives } \\
\text { (Greece) }\end{array}$ & $\begin{array}{l}\text { Job satisfaction is associated with } \\
\text { work autonomy, supervision and } \\
\text { salary. }\end{array}$ \\
\hline $\begin{array}{l}\text { Skinner, } \\
\text { Madison, } \\
\text { Humphries, } 2012\end{array}$ & $\begin{array}{l}\text { To identify factors } \\
\text { contributing to } \\
\text { midwives' job } \\
\text { satisfaction }\end{array}$ & $\begin{array}{l}\text { A quantitative method } \\
- \text { an in-house } \\
\text { questionnaire }\end{array}$ & $\begin{array}{l}550 \\
\text { midwives } \\
\text { (Australia) }\end{array}$ & $\begin{array}{l}\text { The midwives were highly satisfied } \\
\text { with their job. }\end{array}$ \\
\hline $\begin{array}{l}\text { Rodwell, Munro, } \\
2013\end{array}$ & $\begin{array}{l}\text { To determine the effects } \\
\text { of workload, job control } \\
\text { and social support on } \\
\text { subjective well-being } \\
\text { and job satisfaction. }\end{array}$ & $\begin{array}{l}\text { A quantitative method } \\
\text { - a questionnaire (Job } \\
\text { Strain Model) }\end{array}$ & $\begin{array}{l}545 \\
\text { midwives } \\
\text { (Australia) }\end{array}$ & $\begin{array}{l}\text { Job satisfaction may be influenced } \\
\text { by job control and support from } \\
\text { supervisors. }\end{array}$ \\
\hline $\begin{array}{l}\text { Lazarus, Rasch, } \\
\text { Liljestrand, } 2005\end{array}$ & $\begin{array}{l}\text { To determine how } \\
\text { midwives perceive the } \\
\text { current situation of } \\
\text { midwifery in their } \\
\text { country }\end{array}$ & $\begin{array}{l}\text { A quantitative method } \\
\text { - an in-house } \\
\text { questionnaire }\end{array}$ & $\begin{array}{l}274 \\
\text { midwives } \\
\text { (Estonia) }\end{array}$ & $\begin{array}{l}\text { Nearly a half of the midwives were } \\
\text { dissatisfied with their job, the main } \\
\text { reason being salary. }\end{array}$ \\
\hline $\begin{array}{l}\text { Rouleau et al., } \\
2012\end{array}$ & $\begin{array}{l}\text { To explain the impact of } \\
\text { midwives' job } \\
\text { satisfaction on their } \\
\text { turnover and burnout }\end{array}$ & $\begin{array}{l}\text { A quantitative method } \\
\text { - a questionnaire } \\
\text { (Maslach Burnout } \\
\text { Inventory) }\end{array}$ & $\begin{array}{l}226 \\
\text { midwives } \\
\text { (Senegal) }\end{array}$ & $\begin{array}{l}\text { A factor contributing to job } \\
\text { satisfaction was job security; some } \\
\text { of the dissatisfiers were salary and } \\
\text { working environment. }\end{array}$ \\
\hline Bodur, 2002 & $\begin{array}{l}\text { To determine the level of } \\
\text { midwives' job } \\
\text { satisfaction }\end{array}$ & $\begin{array}{l}\text { A quantitative method } \\
\text { - a questionnaire } \\
\text { (Minnesota Satisfaction } \\
\text { Questionnaire) }\end{array}$ & $\begin{array}{l}39 \text { midwives } \\
\text { (Turkey) }\end{array}$ & $\begin{array}{l}\text { The midwives were mostly } \\
\text { dissatisfied with their job. The } \\
\text { dissatisfiers were salary and } \\
\text { working environment. }\end{array}$ \\
\hline $\begin{array}{l}\text { Watson, Potter, } \\
\text { Donohue, } 1999\end{array}$ & $\begin{array}{l}\text { To assess midwives' job } \\
\text { satisfaction }\end{array}$ & $\begin{array}{l}\text { A quantitative method } \\
\text { - a questionnaire } \\
\text { (Dilman's Total Design } \\
\text { Method) }\end{array}$ & $\begin{array}{l}240 \\
\text { midwives } \\
\text { (Australia) }\end{array}$ & $\begin{array}{l}\text { The satisfiers were interactions } \\
\text { with women and autonomy. The } \\
\text { dissatisfiers were midwifery } \\
\text { practice, understaffing and working } \\
\text { relations. }\end{array}$ \\
\hline $\begin{array}{l}\text { Todd, Farquhar, } \\
\text { Camilleri- } \\
\text { Ferrante, } 1998\end{array}$ & $\begin{array}{l}\text { To assess the job } \\
\text { satisfaction of } \\
\text { community and hospital } \\
\text { midwives }\end{array}$ & $\begin{array}{l}\text { A quantitative method } \\
\text { - a questionnaire } \\
\text { (Glasgow Midwifery } \\
\text { Process Questionnaire) }\end{array}$ & $\begin{array}{l}80 \text { midwives } \\
\text { (United } \\
\text { Kingdom) }\end{array}$ & $\begin{array}{l}\text { The attitudes of hospital midwives } \\
\text { towards job satisfaction were } \\
\text { neutral. The community midwives } \\
\text { were more satisfied. }\end{array}$ \\
\hline
\end{tabular}


Table 2 An overview of studies on job satisfaction of midwives included in the literature review (mixed research methods)

\begin{tabular}{lllll}
\hline Author(s), years & Objective & Method & Sample & Results \\
\hline $\begin{array}{l}\text { Ball, Curtis, } \\
\text { Kirkham, 2003 }\end{array}$ & $\begin{array}{l}\text { To find out why } \\
\text { midwives leave their } \\
\text { profession. }\end{array}$ & $\begin{array}{l}\text { Quantitative and } \\
\text { qualitative methods }- \\
\text { an in-house } \\
\text { questionnaire, an } \\
\text { interview }\end{array}$ & $\begin{array}{l}\text { 1016 } \\
\text { midwives } \\
\text { (United } \\
\text { Kingdom) }\end{array}$ & $\begin{array}{l}\text { Five main reasons for leaving the } \\
\text { profession (dissatisfaction with } \\
\text { midwifery, family, retirement, ill } \\
\text { health and planned career } \\
\text { change) }\end{array}$ \\
$\begin{array}{l}\text { Sullivan, Lock, } \\
\text { Homer, 2011 }\end{array}$ & $\begin{array}{l}\text { To identify factors } \\
\text { contributing to } \\
\text { retention of midwives }\end{array}$ & $\begin{array}{l}\text { qualitative methods - a } \\
\text { questionnaire } \\
\text { (Questionnaire by } \\
\text { Kirkham), an interview }\end{array}$ & $\begin{array}{l}\text { 209 midwives } \\
\text { (Australia) }\end{array}$ & $\begin{array}{l}\text { Three main reasons for staying in } \\
\text { the profession were that } \\
\text { midwives enjoyed their job, were } \\
\text { proud to be midwives and got job } \\
\text { satisfaction. }\end{array}$ \\
\hline
\end{tabular}

\section{Discussion}

The study aimed at identifying and analyzing factors influencing job satisfaction of midwives. Job satisfaction is an important aspect influencing work productivity and quality in an organization as well as retention and turnover of midwives. Job satisfaction of midwives is negatively affected by numerous factors and determinants such as autonomy (associated with midwifery competencies), workload, physical demands, understaffing, excessive documentation (Wheeler, Riding, 1994; Sato, Adachi, 2013) or shift work (Paterson et al., 2010). Family commitments have been shown to be among the main factors influencing turnover of health professionals. Women having young children frequently reduce their working hours (Currie, Carr Hill, 2012). Job satisfaction of midwives is also linked to the imbalance between their work and family life (Payne, 2010). The results in this area are identical to those reported in nurses. In a study by Strachota et al. (2003), the main reasons for nurses to change their employment status were family concerns and child care. Similarly, Yamaguchi et al. (2016) found that work-family imbalance results in job dissatisfaction of nurses who subsequently leave their profession. Dissatisfaction with work-family balance is another important determinant having an impact on midwives' job satisfaction. Midwives are also not satisfied with support from their superiors (Gardulf et al., 2008). Poor managerial support leading to inadequate professional development of midwives is perceived as another negative variable of job satisfaction. This was confirmed by Bártlová (2006) in her study on job satisfaction of nurses in the Czech Republic. Here, the second cause of job dissatisfaction (after inadequate remuneration) identified by nurses was a lack of appreciation from their superiors. Another dissatisfier observed in the midwifery profession is salary. Midwives are paid different salaries, depending on the department or region they work in (Lazarus, Rasch, Liljestrand,
2005). In a study determining job satisfaction of general nurses and identifying factors contributing to it, the nurses were the least satisfied with their salary (Lorber, Savič, 2012). According to Bártlová (2006), the factor most contributing to nurses' job dissatisfaction is their salary. Given the character and difficulty of their work, nurses consider their salary as low, perceiving it as the main cause of their dissatisfaction. Although remuneration may seem to be the main determinant of job dissatisfaction and was identified by midwives as the main dissatisfier in their profession, it is not crucial for turnover behavior. There needs to be interaction with other dissatisfiers to constitute job dissatisfaction with salary (Ivanová, Nakládalová, Vévoda, 2012). Midwives also encounter stress in their profession. Surveys carried out in healthcare facilities showed high levels of stress in health professionals resulting from a lack of time for professional activities, high workload, workplace bullying, management styles and job insecurity (Vévodová et al., 2016). All these may lead to physical and mental health problems (Rodwell, Munro, 2013). Nurses also feel physically and mentally exhausted by their work. They experience feelings of sadness, hopelessness, fatigue and exhaustion (Bártlová, 2010; Burešová, Jarošová, 2015). The above factors have a negative impact on midwives' job satisfaction, ultimately leading to turnover (Ball, Curtis P, Kirkham, 2003; Shen, Cox, McBride, 2004). This, in turn, negatively affects work productivity and care effectiveness, reflecting job dissatisfaction. Cortese (2007) confirmed job satisfaction as one of the main factors influencing turnover of health professionals. According to the study, such turnover leads to understaffing and, thus, more working hours and high workload. Great psychological stress, a demanding job and inadequate salary, when combined, lead to employee turnover (Ivanová, Nakládalová, Vévoda, 2012). The results of the present literature review showed that negative components in the midwifery profession prevail over the positive ones that should lead to job satisfaction. 


\section{Limitations of study}

The limitations of this literature review stem from the topic as very little attention has been paid to overall job satisfaction of midwives. Studies involving midwives are more often concerned with workrelated stress, burnout and workload in association with their job satisfaction. More studies can be found on midwives' job satisfaction with respect to job satisfaction of general nurses or other health professionals. Another limitation was language as in the Czech Republic, studies generally concerned with job satisfaction of midwives are completely missing. Therefore, only records in English were searched.

\section{Conclusion}

The literature review presents factors that contribute, either positively or negatively, to job satisfaction of midwives. The review showed that factors negatively affecting the midwifery profession prevail. These dissatisfiers subsequently lead to midwife turnover. A key role in maintaining midwives' job satisfaction is played by their superiors who should actively map the dissatisfiers in the profession and, subsequently, implement strategies that help retain midwives and increase their job satisfaction. Therefore, managers should adequately appreciate the work of midwives and provide them with sufficient support and recognition. Other important factors are ensuring adequate staffing, facilitating the professional development of midwives and allowing them more time to care for women so that midwives are satisfied in their work.

\section{Ethical aspects and conflict of interest}

The authors declare that they have no conflict of interest.

\section{Author contribution}

Concept and design (DJ, DN), analysis and interpretation of data (DN), the drafting of the manuscript (DN, BD), a critical revision of the manuscript (DJ), the final completion of the article (DJ, DN).

\section{References}

Ball L, Curtis P, Kirkham M. Why do midwives leave? Midwifery Matters. 2003;96:8-10.

Bártlová S. Pracovní spokojenost zdravotních sester v České republice. Zdravotnictví v České republice. 2006;4(9):166169. (in Czech)

Bártlová S, Hajduchová H. Psychofyzická zátěž a příčiny fluktuace sester. Zdravotnictví v České republice. 2010;3(13):110-115. (in Czech)
Bodur S. Job satisfaction of health care staff employed at health centres in Turkey. Occupational Medicine (Oxford, England). 2002;52(6):353-355.

Burešová Z, Jarošová D. Kvalita života sester pracujících v nemocnici. Ošetrovatel'stvo, teória, výskum, vzdelávanie. 2015;5(1):13-17. (in Czech)

Casey M, Saunders J, O'Hara T. Impact of critical social empowerment on psychological empowerment and job satisfaction in nursing and midwifery settings. Journal of Nursing Management. 2010;18(1):24-34.

Cortese CG. Job satisfaction of Italian nurses: an exploratory study. Journal of Nursing Management. 2007;15(3):303-312.

Currie EJ, Carr Hill RA. What are the reasons for high turnover in nursing? A discussion of

presumed causal factors and remedies. International Journal of Nursing Studies. 2012;49(9):1180-1189.

Curtis PA, Ball L, Kirkham M. Why do midwives leave? (Not) being the kind of midwife you want to be. British Journal of Midwifery. 2006;14(1):27-31.

Dorrian J, Paterson J, Dawson D, Pincombe J, Grech C, Rogers AE. Sleep, stress and compensatory behaviors in Australian nurses and midwives. Revista De Saude Publica. 2011;45(5):922-930.

Gardulf A, Orton ML, Eriksson LE, Undén M, Arnetz B, Kajermo KN, Nordström G. Factors of importance for work satisfaction among nurses in a university hospital in Sweden. Scandinavian Journal of Caring Sciences. 2008;22(2):151160.

Hammond A, Gray J, Smith R, Fenwick J, SE Homer C. Same... same but different: expectations of graduates from two midwifery education courses in Australia. Journal of Clinical Nursing. 2011;20(15-16):2315-2324.

Hampton GM, Peterson RT. Job satisfaction of certified nurse midwives: an examination. Administrative Issues Journal: Education, Practice and Research. 2012;2(2):112-126.

Ivanová K, Nakládalová M, Vévoda J. Pracovní satisfakce všeobecných sester v ČR podle hodnotových distancí. Pracovni lékařství. 2012;64(4):156-163. (in Czech)

Kumar R, Ahmed J, Shaikh BT, Hafeez R, Hafeez A. Job satisfaction among public health professionals working in public sector: a cross sectional study from Pakistan. Human Resources for Health. 2013;11:2.

Lasovská A, Králová J. Motivace všeobecných sester ke zvyšování kvalifikace. Profese online. 2011;4(1):11-15. (in Czech)

Lazarus JV, Rasch V, Liljestrand J. Midwifery at the crossroads in Estonia: attitudes of midwives and other key stakeholders. Acta Obstetricia et Gynecologica Scandinavica. 2005;84(4):339-348.

Lorber M, Savič BS. Job satisfaction of nurses and identifying factors of job satisfaction in Slovenian hospitals. Croatian Medical Journal. 2012;53(3):263-270.

Mackin P, Sinclair M. Labour ward midwives' perceptions of stress. Journal of Advanced Nursing. 1998;27(5):986-991.

Moher D, Liberati A, Tetzlaff J, Altman DG; PRISMA Group. Preferred reporting items for systematic reviews and meta-analyses: the PRISMA statement. PLoS Medicine. 2009;6(7): e1000097.

Papoutsis D, Labiris G, Niakas DA. Midwives' job satisfaction and its main determinants: a survey of midwifery practice in Greece. British Journal of Midwifery. 2014;22(7):480-486. 
Paterson JL, Dorrian J, Pincombe J, Grech C, Dawson D. Mood change and perception of workload in Australian midwives. Industrial Health. 2010;48(4):381-389.

Payne S. Why midwives fail to stay in practice following a return to practice course. British Journal of Midwifery.2010;18(6):376-381.

Rodwell J, Munro L. Well-being, satisfaction and commitment: the substitutable nature of resources for maternity hospital nurses. Journal of Advanced Nursing. 2013;69(10):2218-2228.

Rouleau D, Fournier P, Philibert A, Mbengue B, Dumont A. The effects of midwives' job satisfaction on burnout, intention to quit and turnover: a longitudinal study in Senegal. Human Resources for Health. 2012;10:9.

Sato K, Adachi K. Occupational stress experienced by Japanese midwives. British Journal of Midwifery. 2013;21(11):801-806.

Shen J, Cox A, McBride A. Factors influencing turnover and retention of midwives and consultants: a literature review. Health Services Management Research. 2004;17(4):249-262. Sidebotham M, Ahern K. Factors influencing midwifery migration from the United Kingdom to Australia. International Nursing Review. 2011;58(4):498-504.

Skinner V, Madison J, Humphries JH. Job satisfaction of Australian nurses and midwives: a descriptive research study. Australian Journal of Advanced Nursing. 2012;29(4):19-27.

Strachota E, Normandin P, O'Brien N, Clary M, Krukow B. Reasons registered nurses leave or change employment status. Journal of Nursing Administration. 2003;33(2):111-117.
Sullivan K, Lock L, Homer CS. Factors that contribute to midwives staying in midwifery: a study in one area health service in New South Wales, Australia. Midwifery. 2011;27(3):331-335.

Todd CJ, Farquhar MC, Camilleri-Ferrante C. Team midwifery: the views and job satisfaction of midwives. Midwifery. 1998;14(4):214-224.

Tummers LG, Den Dulk L. The effects of work alienation on organisational commitment, work effort and work-to-family enrichment. Journal of Nursing Management. 2013;21(6):850-859.

Vévoda J. et al. Pracovní spokojenost všeobecných sester. Profese on-line. 2010;3(3):207-220. (in Czech)

Vévodová Š, Vévoda J, Vetešníková $M$, Kisvetrová $H$, Chrastina J. The relationship between burnout syndrome and empathy among nurses in emergency medical services. Kontakt. 2016;18(1):e17-e21.

Watson L, Potter A, Donohue L. Midwives in Victoria, Australia: a survey of current issues and job satisfaction. Midwifery. 1999;15(4):216-231.

Wheeler H, Riding R. Occupational stress in general nurses and midwives. British Journal of Nursing.1994;3(10):527534.

Yamaguchi Y, Inoue T, Harada H, Oike M. Job control, work-family balance and nurses' intention to leave their profession and organization: a comparative cross-sectional survey. International Journal of Nursing Studies. 2016;64:52-62. 